$11 \mid 1996$

Le développement négocié : courtiers, savoirs, technologies (I)

\title{
How should the bunds be built? Negotiating technologies for soil and water conservation in semi-arid South India
}

\section{Barbara Adolph}

\section{(2) OpenEdition}

Journals

Édition électronique

URL : http://journals.openedition.org/apad/661

DOI : 10.4000/apad.661

ISSN : 1950-6929

Éditeur

LIT Verlag

Édition imprimée

Date de publication : 1 mai 1996

Référence électronique

Barbara Adolph, "How should the bunds be built ? Negotiating technologies for soil and water conservation in semi-arid South India », Bulletin de l'APAD [En ligne], 11 | 1996, mis en ligne le 02 juillet 2007, consulté le 08 septembre 2020. URL : http://journals.openedition.org/apad/661 ; DOI : https:// doi.org/10.4000/apad.661

Ce document a été généré automatiquement le 8 septembre 2020

Bulletin de l'APAD 


\title{
How should the bunds be built? Negotiating technologies for soil and water conservation in semi-arid South India ${ }^{1}$
}

\author{
Barbara Adolph
}

Summary

1 Indigenous soil and water conservation (SWC) measures have been used by farmers. In semi-arid regions of South India for centuries. These structures have often the following characteristics : They are constructed over a relatively long period of time (decades/ generations), requiring little investment at any given time; they use locally available and cheap material ; their establishment and maintenance requires skills that are locally available and they respect property boundaries; they serve farmers 'multiple objectives, and they require a minimum of co-operation. Since colonial times government agencies are trying to impose SWC measures that are either "imported" from other countries with different agro-ecological and socio-economic conditions, or that are developed on research stations, under controlled conditions and with the sole objective of increasing agricultural productivity.

2 Farmers are reacting in various ways to these newly introduced technologies, reaching from the complete dismantling of SWC structures over their modification to their maintenance and improvement. The adoption of new technologies depends largely on the success or failure of negotiations between the farmers (generally through farmers' organisations) and the project implementing agencies. As a result of these negotiations, "on-station technologies" are modified to meet the needs of farmers. Rather than "blanket recommendations" for everyone, agencies are now increasingly trying to develop technologies that are suitable for a particular category of farmers and that are bases on indigenous knowledge. Participatory technology development and planning is used by many NGOs and, more recently, by some government agencies in order to combine farmers' and researchers' knowledge and experience. Several examples for 
such negotiations between farmers and project implementing agencies, that ultimately lead to the modification of external technologies, are presented.

Introduction and background of the study : watershed management in India

3 Farmers in the study area, i.e. the Deccan plateau of South India, have successfully used SWC techniques for centuries, such as the collection of surface runoff in "tanks" (small to medium seized dams made of mud and stones), stone terracing and gully plugging, as well as a range of vegetative measures for soil conservation. However, the steady decline of traditional tank irrigation systems due to socio-economic reasons ${ }^{2}$, together with rapid rural electrification lead to a tremendous increase in privately owned open wells and, more recently, bore wells, with electric pumps. As a result of excessive pumping of ground water for inigation as well as for urban and industrial needs, ground water levels in many parts of the Deccan plateau are declining ${ }^{3}$. At the same time, a large proportion of the rainfall is not utilised, and causes water erosion due to the velocity of surface run-off. Traditional management systems for common property resources such as grazing lands and forests are breaking apart due to encroachment and privatisation of land ${ }^{4}$.

The concept of watershed management as an integrated way to recharge ground water, conserve soil, and increase bio-mass, while at the same time increase agricultural productivity with the help of improved cultivars and cropping patterns, is thought to be a solution to these Problems ${ }^{5}$. Today, we are looking at more than 15 years of experience with watershed management programs in India, implemented by government departments, research institutions, NGOs or a combination of any of these, using a diversity of approaches. However, results have been largely disappointing, despite the amount of public and foreign funds spent on these programs so far. Farmers generally do not maintain SWC structures created under the project, and do not follow the recommended practices once the project support (generally in the form of subsidies and technical assistance) is withdrawn. Project practices have hardly ever spread to neighbouring, non-project areas ${ }^{6}$.

5 Nevertheless, a number of "successful" watershed management projects exist that lead to a sustainable impact on the natural resource base as well as on agricultural productivity and rural incomes ; several such examples were presented at a workshop ${ }^{7}$ in Bangalore in 1994. All the case study projects utilised so-called "participatory" approaches to watershed development. The results of the "New Horizons Project" indicate that increased involvement of farmers in project planning and implementation generally results in a positive project impact.

6 This research project attempts to collect evidence for the positive impact of participatory approaches to watershed management projects such as those being implemented through NGOs and government agencies in India and to ex plain what mechanisms lead to the "success" of participatory approaches. The study consists of two stages; during the first phase in 1994, RRA was used for case studies of 13 watershed management projects in four South Indian states in order to compare approach and impact of these projects. For an in depth study, a case study of two watershed management projects in Anantapur District, Andhra Pradesh, was carried out in 1995 as phase 2. This case study used both qualitative (RIWPRA, including a participatory project evaluation by farmers) and quantitative methods (questionnaire sulvey) to collect evidence for the mechanisms responsible for a particular impact in 
the two project sites, one being NGO managed and the other one being government managed. The paper is based on findings from both phases of the study.

What makes a project work ? Factors associated with "success"

Whether a project is considered to be a success (meaning that it had a positive impact) or not depends largely on what kind of indicators are used 10 measure impact A range of physical and economic indicators, such as meters of bunds constructed and changes in yields ${ }^{8}$, have been used to evaluate the impact of watershed development projects in India and elsewhere. However, sustainable development expresses itself not only in short-term physical and economic achievements, but also in the social changes that take place in a project area and that enable the people in this area to organise themselves, in order to co-operate and to manage and maintain SWC structures.

During the first phase of this research project, it was not possible to quantify neither the physical, nor the socio-economic impact of the projects due to the lack of baseline data Instead, farmers' perceptions of change and own observations were used as proxies for project impact, as it is assumed that a farmer's perception of impact will ultimately determine his or her willingness to adopt and maintain a recommended practice. These indicators are subjective and have not been quantified sufficiently to use them for a thorough project evaluation. The indicators are :

- farmers' perception of changes in the resource base and in productivity as a result of project interventions (average yields of main crops in low and high rainfall years before and after the project, changes in the extent of soil erosion, changes in well water levels and in irrigated area, changes in availability of fodder grasses and fire wood, crop diversification etc.),

- maintenance of SWC measures (includes on-farm measures as well as community structures such as check dams and percolation tanks),

- ability of the community to protect CPR effectively from over-exploitation,

- changes in the status of women, landless and members of low castes as a result of project interventions

9 By giving ratings (on an ordinal scale) to these indicators and comparing these ratings across villages, it was possible to identify certain factors that seem to be associated with "success".

These factors are mostly related to the institutional approach that was used by the implementing agency. In addition, some underlying principles, i.e. the reasons why these factors result in a certain output, were identified :

Table 1 : Factors associated with project "success"

\begin{tabular}{|l||l||l|}
\hline Factor & Underlying Principle & Result \\
\hline \hline \multirow{2}{*}{$\begin{array}{l}\text { High contributions (in } \\
\text { cash or kind / labour) } \\
\text { from farmers for SWC } \\
\text { measures }\end{array}$} & $\begin{array}{llll}\text { Farmers invest only if they are } \\
\text { convinced that the investment } \\
\text { contributes to achieving their } \\
\text { objectives(e.g. income increase or } \\
\text { stabilisation) }\end{array}$ & $\begin{array}{l}\text { Farmers are interested in } \\
\text { maintaining structures in } \\
\text { which they invested }\end{array}$ \\
\hline
\end{tabular}




\begin{tabular}{|c|c|c|}
\hline $\begin{array}{l}\text { Strong Local } \\
\text { institutions }\end{array}$ & $\begin{array}{l}\text { Local institutions are essential to } \\
\text { enforce commonly agreed rules and } \\
\text { regulations relating to SWC(such as } \\
\text { social fencing of grazing land and } \\
\text { forests) as well as to resolve conflicts } \\
\text { within the community }\end{array}$ & $\begin{array}{l}\text { Functioning local institutions } \\
\text { take over management } \\
\text { responsibilities, once the } \\
\text { external project support is } \\
\text { withdrawn }\end{array}$ \\
\hline
\end{tabular}

11 In the following, the focus will be on the second and third point, because here negotiations between interest groups in the context of technology development become most relevant.

Local farmers' institutions - their role in SWC

12 Watershed Management requires collaboration between farmers, as some of the required measures transcend beyond the property of an individual (e. g. water harvesting structures, social fencing of forests and grazing lands, safe run-off disposal both in contour - and boundary based soil conservation systems). Collective action requires social organisation which again is only possible through the community itself. Therefore, local fanners institutions are needed that can motivate and organise the community for collective action, enforce commonly agreed upon rules and regulations, resolve conflicts and that represent the community in matters involving external agencies. These institutions also play a role in assuring that benefits and costs of SWC measures are distributed in a way that induces the necessary (if not the maximum) number of farmers to participate.

Local farmers' institutions that were either established as part of the watershed program were found in 9 out of 13 project studied in phase 1 . However, there were large differences in their organisation, activities, and membership composition (see table 2). As the table shows, women's sanghas are the most common local institutions. However, only in one project the women's sangha is involved in planning and implementation of watershed works. While the importance of local institutions for organising people to co-operate, to enforce rues and regulations and to resolve conflicts has been pointed out above, there is little evidence that this is put into practice Only in six projects the local institutions are actively involved in the watershed programs for planning (e.g preparation of a treatment map) and organising labour for the implementation of SWC works. Among these six, one project (MYRADA PIDOW : Mysore Resettlement and Development Agency / Participatory and Integrated Development of Watersheds) is using a micro-watershed approach. The ration ale behind this lies in the easier manageability of small, homogenous group with similar interests ("stake holders"), who can later send representatives to general meetings, when issues are discussed that extend beyond the micro-watershed.

Table 2 : Local institutions in watershed management projects

\begin{tabular}{|l|l|l|l|l|l|l|l|l|l|l|l}
\hline Local Institution & Members \\
\hline
\end{tabular}




\begin{tabular}{|c|c|c|c|}
\hline $\begin{array}{l}\text { watershed } \\
\text { commitee }\end{array}$ & $\begin{array}{l}\text { planning of SWC works, organisation } \\
\text { of work force, resolving of conflicts } \\
\text { related to WS works, sometimes } \\
\text { saving }\end{array}$ & $\begin{array}{ll}\text { representatives } & \text { from } \\
\text { each community } & \text { (only } \\
\text { men) } & \end{array}$ & 3 \\
\hline $\begin{array}{l}\text { micro-watershed } \\
\text { sangha }\end{array}$ & $\begin{array}{l}\text { Planning and implementation of } \\
\text { SWC works in their micro- WS, } \\
\text { solving conflicts, saving and credit } \\
\text { to members }\end{array}$ & $\begin{array}{l}\text { people with land in the } \\
\text { same micro- WS (mostly } \\
\text { men) }\end{array}$ & 1 \\
\hline $\begin{array}{l}\text { thrift co-operative } \\
\text { savings group }\end{array}$ & $\begin{array}{l}\text { collecting money from the members } \\
\text { and rotating in among them; taking } \\
\text { of loans from bank with saving as } \\
\text { security }\end{array}$ & $\begin{array}{l}\text { women only or(seldom) } \\
\text { men only, usually from } \\
\text { the same community }\end{array}$ & 2 \\
\hline $\begin{array}{l}\text { co-operative } \\
\text { societies, sanghas }\end{array}$ & $\begin{array}{l}\text { obtaining subsidised inputs and } \\
\text { distributing it among members; } \\
\text { occasionally shared inputs (e.g. } \\
\text { sprayers) }\end{array}$ & $\begin{array}{l}\text { men only or men and } \\
\text { women across all } \\
\text { communities }\end{array}$ & 3 \\
\hline $\begin{array}{l}\text { mahila mandal } * * \\
\text { women's sanghas }\end{array}$ & $\begin{array}{l}\text { income generating activities, small } \\
\text { scale loans, training and awareness } \\
\text { creation programs, are entitled to } \\
\text { special govt programs }\end{array}$ & women only & 8 \\
\hline $\begin{array}{l}\text { tree } \quad \text { growers' } \\
\text { society }\end{array}$ & $\begin{array}{l}\text { planting of trees on community land } \\
\text { protection of trees }\end{array}$ & $\begin{array}{l}\text { representatives of all } \\
\text { families in the village }\end{array}$ & 1 \\
\hline $\begin{array}{l}\text { community well } \\
\text { users' group }\end{array}$ & $\begin{array}{l}\text { managing community bore well } \\
\text { (water distribution, maintenance) }\end{array}$ & $\begin{array}{l}\text { Bore well users (mostly } \\
\text { men) }\end{array}$ & 1 \\
\hline
\end{tabular}

$14 *$ number of study villages in which such organisations were present (total number of villages $=13$ )

** often formed as part of government program, not by watershed management project

MYRADAs experience over the past years also showed that watershed activities need to be linked to income generating activities in order for people 10 be motivated enough to invest time for group meetings and 10 participate in the planning of conservation activities All the watershed groups that were found in the 13 villages are involved in such income generating activities, mostly related to thrift and credit groups, training activities and bulk purchase of agricultural inputs. As described by Fernandez ${ }^{9}$, the thrift and credit groups also serve as a learning experience for farmers :

"The members of credit groups acquired considerable management experience while conducting the affairs of the SHCs (selfhelp groups). They learned to set priorities, to take decisions and risks, to draw up rales of behaviour, to resolve conflicts and to apply sanctions effectively for non compliance (...) They acquired the skills required to sustain co-operation and to set up and maintain the systems necessary (like records) to make co-operation a regular behaviour pattern in a word to institutionalise cooperation. These skills and systems are absolutely necessary for 
managing the resources of a watershed (...) The seyhelp group therefore provides a training situation, using credit as a tool or instrument"

The self help groups are thus equipped to negotiate the design and location of SWC structures with the project implementing agency. While individual farmers in projects without local resource management institutions find it difficult to argue with the project authorities about the type of work to be done, groups with a minimum of management skills can have significant influence on government policies at least at the local level.

Indigenous SWC measures

The incorporation of indigenous technologies evolved as another crucial factor contributing to "success" of SWC projects. It is important to distinguish between indigenous ideas and indigenous technologies, because local people often have ideas that cannot be put into practice due to various constraints. This observation was made by Dr. N.K. Sanghi ${ }^{10}$ when working with farmers and a local NGO on the conversion of irrigation tanks into percolation tanks in Anantapur district of Andhra Pradesh. Farmers had been aware of the potentials of such a conversion, but were unable to carry it out without getting external assistance to solve the conflicts between interest groups that would arise from this measure.

Outsiders will only come to know about these local ideas if they establish a close interaction with the local people. This is often not the case when scientists and project implementing agencies approach a village. It is easier to observe the manifestation of such local ideas, i.e. the indigenous technologies that have been put into practice. A wide range of such local technologies for soil and water conservation were observed in the study villages. The most common ones are :

- farm bunds made of earth or stones to reduce erosion, keep water, fertiliser and manure in the field and demarcate the property boundary, often strengthened with stones on week, points,

- agave planted along nallahs (small streams, often seasonal) and field boundaries, in the former case to stabilise nallah bank and in the latter to strengthen bunds and keep cattle and wild pigs out of the field,

- terracing/levelling of fields through bunds (usually boulder/stone walls) ; these walls can reach a height of 10 to 15 meters over several decades, as the height is increased gradually from year to year; this is done on fenile land with slight to medium slopes,

- deposition fields : nallahs are blocked with stones to trap silt ; the stone wall is gradually increased in height and large deposition fields can thus be created ${ }^{11}$,

- nallah bunds constructed by farmers to store water and collect sediments, creating a fertile small field where high value crops are grown The difference between fanners technologies and project technologies are ${ }^{12}$ :

- Farmers invest selectively in soil conservation ; fertile land is given priority, levelling is more important than soil conservation (particularly in fields near wells that can at times be irrigated).

- Farmers invest gradually, increasing the height of structures from year to year.

- Fanners combine soil conservation measures with other objectives (agave for robe-making, bunds for fodder and tree cultivation, small stone bunds for boundary demarcation). While the advantages of local technologies, both in terms of cost efficiency and maintenance as well as acceptability to local people are evident, few of the implementing agencies that were visited actually incorporate them into the project design. The reasons given are : 
- Local technologies are not "scientific" and do not conform with the standards given under NWDPRAI ${ }^{13}$ and other government programs.

- Most of the contractors who are building water harvesting structures are not familiar with local designs and are generally reluctant to try them out.

- Local technologies are very site-specific; it is therefore more time-consuming to select a suitable technology for the various locations other than to use a standard technology for all locations.

21 The large advantage of local technologies is the fact that they are generally cheaper to implement and to maintain. If a locally designed check dam costs only a fifth of a project designed one, it might be more useful to construct five local structures instead of one that meets project standards and retain at least the same quantity of run-off. There is definitely a research need into the effectiveness of local SWC structures and the comparative advantages in terms of construction and maintenance costs.

Examples for negotiations : "technical" versus "social" solutions

The following examples illustrate how incompatibilities between project technologies and farmers' needs can be bridged, if a negotiation process takes place between the various actors involved. The examples are mostly based on own observations and do not claim to be representative.

"Ridge to valley" versus "good landfirst" : negotiating where to start

Technically, the "ridge to valley" approach is propagated as the only sustainable way for watershed management activities. According to this approach, the upper reaches of a watershed should be treated first in order to reduce the velocity of surface run-off and thus to prevent the siltation of reservoirs downstream. The upper reaches should ideally have a permanent tree coyer to facilitate infiltration and to reduce erosion.

However, farmers generally give more importance to protecting high-value land in the valleys, other than treating risk prone, unproductive land in the upper reaches. Farmers in the lower reach often see soil erosion as an opportunity to harvest silt other than a problem. By creating fertile micro-environments, an optimal base for a secure crop is provided. At the same time, fanners with land in the upper reaches cannot change their annual farmland to perennial horticulture or forest plots, as they seldom have the financial capability to wait for the trees to pro vide an income. These farmers are often not able to implement soil conservation activities without external assistance, as the returns to investment are marginal. In addition, the upper reaches of a watershed often belong to the government (forest department), which again hinders their integration into an overall treatment program.

25 In the MYRADA/PIDOW project, the self help groups negotiate together with the project implementing agencies the treatment plan, inc1uding where to start with what measures.

Generally a compromise is found that supports regeneration of the upper catchment, while allowing farmers to take the initiative to harvest silt lower down. Because of the experience gained in the self help groups, farmers are aware of the benefits of co-operation and are more willing to seek for a solution that involves all.

"Contour bunds" versus "boundary bunds" : second best is best

Another "text book" recommendation concerns the location of erosion control measures. As a result of trials and simulations, it was found that contour parallel bunds, or, in areas with higher rainfall, graded bunds (with a slight slope towards a central 
run-off disposal drain) provide the best erosion control effect. Such contour bunds (usually made of soil and stabilised with a grass coyer) have been implemented by numerous government programs (among others under various employment insurance schemes) in India with little success. In Most cases, the bunds were removed by farmers within a few seasons.

The reasons for this are obvious. Contour bunds cut across field boundaries, thus creating insecurity of land ownership and disputes among neighbours. They also obstruct farm operations, as contour parallel ploughing is more difficult and plots are cut into small pieces that are difficult to till. Finally, in areas with shallow soils, the construction of earthen contour bunds adversely effects crop yields, if the top soil is scraped off to construct the bund.

Farmers strongly oppose contour based measures, especially if plot seizes are small. In projects where farmers were involved in the planning of conservation measures, they generally opted for boundary based structures. In order to prevent the breaching of bunds in the corners, waste weirs can be constructed for safe runoff-disposal from field to field. If the structures are placed where fanners want them, they are better maintained ; thus "second cost" becomes "best".

In recent years boundary bunds have become a well accepted alternative for contour bunds, not only with the NGOs. Out of 13 projects visited, only three (all government projects) promoted contour based soil conservation measures on cultivated land (another five projects constructed contour bunds on revenue land or private wasteland / grazing land). Wherever contour bunds were constructed on cultivated land, they were either neglected or purposefully removed, because farmers feel that they obstruct farm operations. Where projects mainly strengthened existing farm bunds or promoted the construction of new farm bunds, the acceptance was much higher.

Design matters : multipurpose boulder bunds

31 Not only the location, but also the design of erosion control bunds is important Development agencies promote trapezoid shaped boulder bunds, where the vertical side is not towards the boundary with the farmer below, but the other way around. This shape is supposed to make the bund more sturdy. However, farmers prefer if the vertical side coincides with the boundary, so that the neighbours field is not encroached. Similarly, farmers give preference to boulder bunds that act at the same rime as walls to keep straying cattle out These walls need to be larger than bunds constructed for erosion control only. Again it becomes clear that fanners have multiple objectives in mind, whereas the "external" solution serves only one purpose.

The study showed that farmers are more willing to contribute their own labour and resources to the construction of SWC measures, if they can implement their own design.

From "irrigation tanks" to "percolation tanks "and vice versa : adapting an traditional technology to today's needs.

33 Traditional irrigation tanks were constructed in India before the existence of diesel engines to lift water from open wells or the drilling of tube wells. The primary purpose of these tanks was to provide water for surface irrigation (only in the command area of the tank) and for cattle and household purposes: As the utilisation of groundwater increases and wells are drying up as a result of depletion of aquifers, groundwater recharge is becoming one of the focal points of watershed management. 

establish trees, no matter how drought resistant the selected species are. An NGO in Anantapur District of Andhra Pradesh suggested to farmers in the project area to protect patches of common (panchayat) land from grazing in order to let the natural vegetation recover. The self-help groups in each hamlet were responsible for the protection of the land and were given the usufruct rights over whatever was produced from these plots (fuel wood, fodder, minor forest products). Before the NGOs intervention, such a measure was not possible due to the lack of organisation from the farmers. After undergoing a learning process in co-operation and connect resolution, the self-help groups were able to protect these lands efficiently at a cost much lower than the cost of afforestation

Conclusion

The examples given above illustrate that development agencies have a lot to learn from local knowledge and technologies. These are often well adopted to risky environments, succeeding in getting the most out of the scarce resources avail able. If technically sound solutions to degradation problems are rejected by farmers, there are usually a multitude of reasons for this. A suitable technology not only needs to preserve the natural resource, but also meet farmers multiple objectives, such as protecting land from intruders, providing additional income, avoiding conflicts with neighbours, and 
minimising labour requirements. Thus, a technically "second best" solution can easily be the overall number one. Flexibility a willingness to learn is a pre-requisite for development interventions and a participatory approach that involves fanners in all stages of the projects seems to be the most promising solution.

However, it was also shown that "traditional is not always beautiful". Under the existing power configuration, with wealthy farmers occupying a large part of the lower reaches, while poor farmers tend to live in the upper and middle reaches, it is often difficult to achieve an equitable and sustainable use of natural resources. Again there is a demand for agencies that are able to mobilise fanners to co-operate and to identify solutions that are acceptable to all. The formation of local self-help group as encouraged by MYRADA in India can be a viable tool in achieving more equity and in reducing conflicts over natural resource utilisation.

Acknowledgement

The author would like to thank the following persons and institutions for their contribution to the findings presented in this paper: Farmers from the study villages and watersheds for sharing their knowledge and experience with my team ; Ms. Arpita Madnanth Rao, Poonam Jaiswal, Praveena Reddy, Tanuja P., Usha Kulkami, and Vasantha Udai Rarn for their excellent work in data collection and data entry ; and Dr. T.G. Kelley (ICRISAT), Dr. N.K. Sanghi (MANAGE), Dr. J.M. Kerr (IFPRI), Dr. M. von Oppen (University of Hohenheirn), Mr. Sheshadri Naidu (MYRADA), and Dr. J.N. Pretty (IIED) for many fruitful discussions and valuable suggestions for the study.

\section{BIBLIOGRAPHIE}

Arnold J.E.M. and Stewan W.C. (1991) Common property resource management in India Tropical Forestry Papers $n^{\circ} 24$. Oxford : Oxford Forestry Institute.

Fernandez AP. (1994). 2nd edition. The MYRADA experience The interventions of a voluntary agency in the emergence and growth of peoples' institutions for sustained and equitable management of micro-watersheds. Bangalore (India) : MYRADA

Gangi Reddy P., Sriramappa G., Katyal J.C., Sanghi N.K., and Kerr J.M. (1994) Convening Irrigation Tanks into Percolation Tanks in South India : A Case Study of Social Organisation Leading to Equitable Development. Paper prepared for The New Horizon Conference on Participatory Watershed Development, Bangalore, November 28 to December 2, 1994.

Gregersen H.M., Brooks K.N., Dixon J.A. and Hamilton L S. (1988) Guidelines for economic appraisal of watershed management projects FAO Conservation Guide 16 Rome : FAO.

Hinchcliffe F., Guijt I., Pretty J.N et al (eds ) (1995) The economic, social and environmental impacts of participatory watershed development. Gatekeeper Series $n^{\circ} 50$ London : IIED.

Kerr J.M. and Sanghi N.K. (1992) Economic Determinants of Indigenous Soil and Water Conservation Investments. In Papers presented at the Workshop on "Management of the Natural Resources by People", 14-23, January 19-21, 1992, Hyderabad. Hyderabad : Youth for Action. 
Moench M. (1992). Drawing down the buffer. Science and politics of ground water management in India. Economic and Political Weekly March 28, A7 - A14.

von Oppen M. and Subba Rao K.V. (1982). History and Economies of Tank Irrigation in Semi-Arid Tropical India In Symposium on Rainwater and Dryland Agriculture, 54-75. Delhi : Indian National Science Academy.

von Oppen M., and Knobloch C. (1990). "Composite watershed management : A land and water use system for sustaining agriculture on alfisols $\mathrm{h}$ the semiarid tropics". Journal of Farming Systems Research-Extension 1(1) :37-54.

Pretty J.N. (1994). "Alternative systems of inquiry for sustainable agriculture". ids bulletin 25 (2) : 37-48.

Rajagopalan V. (1991). "Integrated watershed development in India : Some problems and perspectives". Indian Journal of Agricultural Economics 46(3):241-250.

Rajashekar B.G., and Sanghi N.K. (1993). Report of the ITTs (Indigenous Technology Team) mission in PIDOW Gulbarga Project Unpublished report, Bangalore : MYRADA.

Shah P. (1993) Participatory watershed management programmes in India : Reversing our roles and revising our theories In Rural people's knowledge, agricultural research and extension practice. Asia Papers. Research Series Vol. 1, No. 3. London : IIED, pp 38-67.

\section{NOTES}

1.This paper documents some of the outputs of the research project "Socio-economic conditions and institutional requirements for farmers' participation in watershed management programs in the semi-arid tropics of South India". The project, financed by GTZ (German Agency for Technical Co-operation), is carried out in collaboration between ICRISAT (International Crops Research Institute for the Semi-arid Tropics) in Patancheru, India, and the Institute of Agricultural Economies and Social Sciences in the Tropics and Sub-Tropics, University of Hohenheim, Germany. Project duration is from November 199310 October 1996.

2.See von Oppen and Subba Rao (1982) for details on tradional tank irrigation in South India.

3.Moench (1992).

4.See Arnold and Stewart (1991) for a review of CPR management in India.

5.See von Oppen \& Knobloch (1990) for the emergence of the wateshed management concept in India.

6.See Rajagopalan (1991) for problems related to watershed development in India. 7.The workshop "New Horizons : The economic, environmental and social impacts of participatory wotershed development" in Bangalore, November 1994, summarised the findings of a collaborative research project, co-ordinated by IIED (International Institute for Environment and Development) in London, and involving researchers and practitioners from six countries. See Hinchclife \& al. (1995).

8.See Gregerson \& al. (1988) on methods for the economic evaluation of watershed management programs.

9.Fernandez (1994), p. 137.

10.Director. National Institute for Agricultural Extension Management, Hyderabad. India. 
11.Kerr and Sanghi 1992.

12.Own observations and Kerr \& Sanghi 1992.

13. National Watershed Development Program for Rainfed Areas ; a program under the MoA.

14.See Gangi Reddy et al. (1994) for details on the tank conversion experience in Anantapur.

\section{AUTEUR}

\section{BARBARA ADOLPH}

University of Hohenheim, Germany 